\title{
Regenerative Braking for Energy Recovering in Diesel-Electric Freight Trains: A Technical and Economic Evaluation
}

\author{
Sergio Mayrink Jr. ${ }^{1}$, Janaína G. Oliveira ${ }^{2,3}$, Bruno H. Dias ${ }^{2, *}{ }^{\circledR}$, Leonardo W. Oliveira ${ }^{2}$, \\ Juan S. Ochoa ${ }^{3}$ and Gustavo S. Rosseti ${ }^{4}$ \\ 1 MRS Logística, Juiz de Fora 36015-000, Brazil; sergio.mayrink@engenharia.ufjf.br \\ 2 Department of Electrical Energy, Federal University of Juiz de Fora (UFJF), Juiz de Fora 36015-000, Brazil; \\ janaina.oliveira@ufjf.edu.br (J.G.O.); leonardo.willer@ufjf.edu.br (L.W.O.) \\ 3 Division for Electricity, Uppsala University, 75236 Uppsala, Sweden; juan.santiago@angstrom.uu.se \\ 4 Federal Institute of Education, Science and Technology of Southeast of Minas Gerais, Santos Dumont \\ 31270-901, MG, Brazil; gustavo.rosseti@ifsudestemg.edu.br \\ * Correspondence: bruno.dias@ufjf.edu.br; Tel.: +55-32-21023495-222
}

Received: 8 January 2020; Accepted: 19 February 2020; Published: 21 February 2020

\begin{abstract}
The present work evaluates the application of regenerative braking for energy recovery in diesel-electric freight trains to increase efficiency and to improve decarbonization. The energy from regenerative braking has to be stored onboard when the track is not electrified. Different technologies of energy recovery are presented and discussed. The energy balance of an existing route is presented and simulated for different battery sizes. The analysis is illustrated with experimental data from an important Brazilian railway. Results show that the energy recovery from regenerative brake is a feasible investment and may be recommended to increase the efficiency in transportation and also to improve the low carbon mobility in railway systems.
\end{abstract}

Keywords: regenerative braking; energy storage; railway; economic feasibility

\section{Introduction}

The use of railway systems in the transport sector presents advantages relative to other systems regarding energy efficiency, environmental impact, reliability, security and economic feasibility [1,2]. Railways present some common characteristics. The friction coefficient is very low resulting in low friction. As a result, the track gradient has to be very gentile due to the low friction coefficient. High peak power is demanded during braking and uphill climbing [3], creating big differences between average power and peak power in freight trains considering storage and diesel demand, respectively.

New infrastructure comprising electrification, improved operation through the optimization of timetables for maximizing the use of the regenerated energy [4], as well as storage devices [5] are ways of increasing the transport efficiency of a railway system. Regenerative braking is an interesting technology to increase efficiency [6,7], consisting of inverting the propulsion machine functioning mode from motor to generator. It is feasible for locomotives with electric traction motors, both electric and diesel-electric.

With the purpose of maximizing the regenerated energy, the Bellman-Ford algorithm has been used in [8] to optimize the braking and speed of a train. The train speed optimization is also proposed in [9] under the point of view of the energy recovered in the braking in different scenarios. Another optimization approach, based on the dual speed curve method, is presented in [1], to determine the effective speed curve for maximizing the energy economy. In [10] the authors present a comparison between different storage configurations in regenerative braking systems of locomotives, in railways 
electrified by a micro DC network connected to the electrical network by a unidirectional substation. The referred work proposes a braking system with a control algorithm that considers the mass variation and the resistances that participate in the breaking, pointing out the off-board system as the more interesting in the considered condition.

Research on advantages and drawbacks of different technologies applied to regenerative braking of locomotives can also be found in the literature. Recent applications of systems with batteries, flywheels, capacitors, and hybrid devices are described in [11]. Information on specific capacity of permanent and temporary batteries for saving energy is given in [12]. Data on energy density, lifetime and operating temperature of batteries, in turn, are presented in [13]. A review of technologies for the management of regenerative braking energy is made in [2], which comprises reversible substations and tariff scenarios. Ultracapacitors are considered in [14], for a hierarchical control strategy that consists of energy management and converter control layers in urban railway, as well as in [15], through practical examples of eco-friendly solutions implementation in urban municipal transport.

The methodology proposed in [13] seeks to determine the sizing of a hybrid energy storage system for regenerative braking involving batteries and ultracapacitors. The advantage of the hybrid system is to combine the energy capacity of the batteries with the power density of ultracapacitors. Electrochemical double-layer capacitors and Li-ion batteries are evaluated as storage options. In [16], a methodology is proposed for optimal operation of railway electric energy systems considering renewable energy sources (solar panels and wind turbines), regenerative braking capabilities and hybrid electric energy storage devices (ultracapacitors and batteries). The authors of [17] presented an optimized sizing and scheduling of hybrid energy storage systems for high-speed railway traction substations integrated with removable energy, with the intention of minimizing the total cost throughout the project service period. The battery degradation and replacement cost were taken into account.

On the other hand, the onboard storage is indicated as the most worthwhile option in [18] for diesel-electric locomotives in non-electrified railways. A small size fuel cell based on a proton exchange membrane (PEM) is evaluated in [19] for energy management of a train with a focus on the maximum propulsion system efficiency, considering losses in auxiliary components. The efficiency is assessed both for individual components and the integrated propulsion system during steady-state and dynamic conditions, under different control strategies. The analysis performed in [20] evaluates the potential energy recovery from regenerative braking of diesel-electric locomotives in freight service, by using and comparing locomotive event recorder data with results obtained from computer simulations. The purpose is the sizing of the storage capacity by carrying out economic and environmental analyses that consider, among the candidate technologies, batteries, supercapacitors, and flywheels. The context is near the Brazilian railway scenario. However, the economic feasibility analysis should be updated regarding technologies and scale gains.

The analysis of energy recovering and storage in locomotives consists of an open and promising topic for research, particularly concerning the more suitable alternatives for a given type of system and its interactions [21]. Moreover, most of the studies are devoted to systems for electric locomotives, whereas the number of contributions for diesel-electric locomotives in non-electrified railways is still relatively low. Such systems can operate in an independent way, where each train can be considered as a microgrid with onboard generation and consumption.

Following the previously described research line and the relative lack of works for diesel-electric locomotives in non-electrified railways, the present work seeks to evaluate the application of onboard regenerative braking for energy recovery in freight trains, considering a realistic scenario for a Brazilian railway system and real technical aspects of the storage devices. The objective is to present an approach to determine the recoverable energy potential from the application of an energy storage system (ESS) and to maximize net present value (NPV).

The paper is outlined as follows. Section 2 introduces the general energy recovery and storage devices in railway systems. Section 3 details the proposed methodology to estimate the recoverable energy from regenerative brake systems and also the investment analysis tools used to evaluate the 
ESS. In Section 4, the case study comprising a Brazilian railway is presented as a case study together with the results for this system. Finally, conclusions are drawn in Section 5.

\section{Energy Recovery in Railway Systems}

Different technologies and interdependencies between subsystems, like vehicles, operation, and infrastructure have been investigated for regenerative braking [22-25].

Energy recovered from regenerative braking can be stored onboard or injected to the grid through the catenary. The power injected in the catenary can be returned to the grid only if the railway substation is prepared for bidirectional operation. Railway substations are usually not bidirectional, so the recovered energy has to be used either by another train running in the same line, stored locally at the substation, or dissipated in resistance [26]. Diesel-electric trains are not connected to a catenary to return the regenerative braking energy and have to dissipate the braking energy in resistances. The only options to recover the energy are either to use it in onboard consuming systems or to store it, also onboard. On-board storage systems offer the advantage of reducing the energy consumption, however, they add larger weight for the train with its related energy demand, as well as an increase in cost and maintenance requirements [7,27]. There are only two alternatives for regenerative braking for trains not connected to a catenary. The train can either have an ESS that can store the energy for long drive cycles or connecting points may be installed along the line at planned stops and reduce the size of the energy storage [15].

\section{Storage Devices}

Different kinds of ESS are available and they are generally classified based on the kind of energy in use: electrochemical, electrical, mechanical, chemical, or thermal. Some examples are depicted in Figure 1.

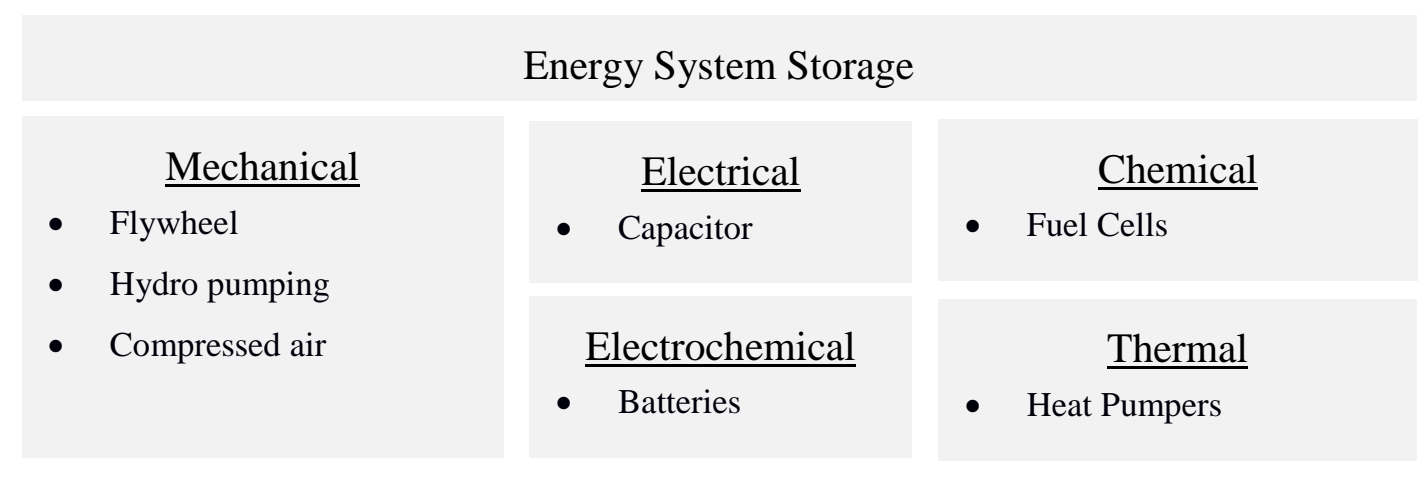

Figure 1. Classification of storage systems (adapted from [28]).

The most adequate storage device can be determined by the system main characteristics, such as specific energy $(\mathrm{Wh} / \mathrm{kg})$, specific power $(\mathrm{W} / \mathrm{kg})$, and charge/discharge cycle duration, among others [29]. The main alternatives to be used in the energy recovery from regenerative braking are batteries [30,31], supercapacitors [32,33], and flywheels [34,35]. Among them, the batteries are the most adequate for freight trains [36].

The main advantages of the batteries are reliability, low maintenance, safety, and good energy density. Additionally, as an advantage, it presents a wide range of sizes, values of the nominal power, voltages, and configurations. On the other hand, batteries are still a high-cost solution, with a low power density (thus presenting high weights in some applications). In addition, a drawback is the use of materials that can harm the environment and a short lifespan [37]. 


\section{Methodology}

This section presents the energy balance related to the movements of trains. Thus, a method to estimate the potential energy recovery from regenerative braking is presented. Additionally, this section shows the choice and sizing of the storage device, as well as the economic analysis used to choose the best option.

\subsection{Energy Balance-Train Movement}

There are a number of forces involved in the train's drive cycle. The forces are grouped in the thrust, as the positive thrust of brake force $\left(W_{\text {mot } / \text { brake }}\right)$, the friction forces $\left(W_{\text {friction }}\right)$ representing power losses, and the railway profile, descending or ascending, representing the weight component parallel to the ground that contributes to the gain or loss of potential energy $\left(W_{\text {gravity }}\right)$. The force balance is presented in Equation (1) gives the exceeding force that contributes to the train's acceleration.

$$
F_{\text {acceleration }}=M \cdot W_{\text {acceleration }}=F_{\text {mot } / \text { brake }}-F_{\text {friction }} \pm F_{\text {gravity }}
$$

Each term of Equation (1) will be detailed.

\subsubsection{Power Term Related to Friction Losses}

The friction losses can be estimated with the classical experimental model that considers the resistance forces proportional to the speed in a second-order equation, also known as the Davis' equation, seen in Equation (2), which gives the friction coefficient.

$$
\gamma_{a t}=A+B \cdot v+C \cdot v^{2}
$$

The terms $A, B$, and $C$ are obtained through experimental results. The calculation of these coefficients for locomotives and wagons are described in Table 1.

Table 1. Davis' equation coefficients [38,39].

\begin{tabular}{cccc}
\hline Vehicle & A & B & C \\
\hline 1st locomotive & $0.65+\frac{13.15}{\frac{M}{n}}$ & 0.00932 & $0.00456 \cdot \frac{S}{M}$ \\
\hline 2nd locomotive & $0.65+\frac{13.15}{\frac{M}{n}}$ & 0.00938 & $0.00115 \cdot \frac{S}{M}$ \\
\hline Wagon & $0.65+\frac{13.15}{\frac{M}{n}}$ & 0.01405 & $0.000945 \cdot \frac{S}{M}$ \\
\hline
\end{tabular}

From the friction coefficient, the force resulting from the resistance to the movement can be found as presented by Equation (3).

$$
F_{\text {friction }}=\frac{\gamma_{a t} \cdot M \cdot g}{1000}
$$

From the previous friction force, the friction power losses can be calculated as shown in Equation (4).

$$
P_{\text {friction }}=F_{\text {friction }} \cdot \frac{v}{3.6}
$$

Therefore, given the main features of the vehicles, such as mass, the number of axes, and frontal area, it is possible to estimate the friction as a function of velocity, by combining Equations (2)-(4), together with the coefficients from Table 1 .

\subsubsection{Power Term Related to Gravity}

Gravity can have a positive or negative impact on the energy balance of the train's movement. Railway profiles do not present high inclinations because of the low friction coefficient between wheel 
and rail. Those inclinations are represented as a percentage value. For example, a ramp has $1 \%$ inclination if it presents a vertical variation of $1 \mathrm{~m}$ for $100 \mathrm{~m}$ of horizontal movement. That is, the tangent of the inclination angle is 0.01 .

The necessary power for the train to climb a ramp can be described as presented in Equation (5).

$$
P_{\text {gravity }}=F_{\text {gravity }} \cdot v=\frac{M_{\text {train }} \cdot g \cdot \tan (\alpha) \cdot v}{3.6}
$$

\subsubsection{Power Term Related to the Motor or Brakes}

The power provided by the locomotive is given by the throttle position, since the fuel consumption depends on the throttle position or notch, as presented in Table 2 for the studied locomotive.

Table 2. Estimated fuel consumption by throttle notch [20].

\begin{tabular}{cc}
\hline Throttle Notch & Estimated Consumption (L/h) \\
\hline Dynamic Brake & 17 \\
\hline Neutral & 12 \\
\hline 1 & 45 \\
\hline 2 & 90 \\
\hline 3 & 180 \\
\hline 4 & 250 \\
\hline 5 & 330 \\
\hline 6 & 470 \\
\hline 7 & 600 \\
\hline 8 & 700 \\
\hline
\end{tabular}

The throttle presents 10 positions: eight acceleration points, neutral notch, and dynamic brake. The dynamic brake is controlled by a second lever that can vary continuously from the minimum to the maximum point. These values are registered in the black box in a percentage range, from $0 \%$ to $100 \%$, representing the increasing level of energy dissipation in the resistor banks of the dynamic brake.

It is possible to extract the number of times the acceleration lever has been used in each position during the trip, and therefore the fuel consumption and energy demand at each point. Additionally, the number of times and percentage usage of the dynamic brakes can be extracted. Thus, the first step to the proposed approach is to evaluate a complete trip.

Considering that the energy density of the diesel oil is $11.1 \mathrm{kWh} / \mathrm{L}$, the consumption can be rewritten in terms of power, as presented in Equation (6).

$$
P_{\text {mot } / \text { brake }}=\frac{\rho \cdot S C}{1000} \cdot \eta_{\text {diesel }}
$$

The power dissipation in the resistors' banks is related to the use of the dynamic brake. To define this relation, the data from the black box of different locomotives in different parts of the railway are depicted in Figure 2. A strong linear correlation between these two variables can be seen.

A linear approximation of the data displayed in Figure 2 is presented in Equation (7) and gives the power dissipated as a function of the dynamic brake use, as a percentage.

$$
P_{\text {brake }}=40.849 \cdot(\% F D)+94.67
$$

The measured point at high dynamic brake usage with low power dissipation corresponds to moments when the locomotive is moving slow, so little energy can be converted before the train stops. The breaking power behavior is linear other than the moments at very high or low speed. From the 
previous information of power demand, obtained by the acceleration or braking points from the black boxes, a demand profile can be estimated for the complete trip. Those steps will be developed afterwards and are the basis of the storage system dimensioning and preliminary financial analysis.

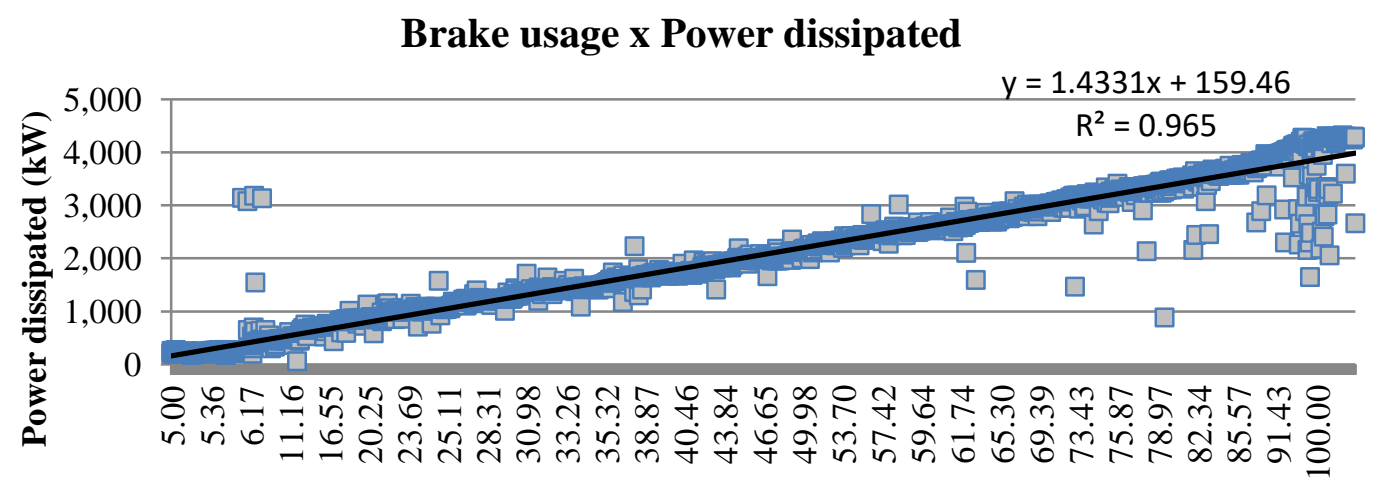

Dynamic brake usage (\%)

Figure 2. Relation between the use of a dynamic brake and the power dissipated.

\subsubsection{Power Term Related to the Resulting Forces}

The energy balance considers the mechanical energy conservation and energy losses due to the friction and dissipation in the brakes. There is a resulting force that acts accelerating or deaccelerating the train when the friction and the gravity in the direction of the movement are other than zero, as ruled by Newton's second law.

It must be observed that the freight trains work in a more constant velocity when compared to passenger trains. Thus, the locomotive runs in many parts of the railway at a constant velocity, so there is no resulting force. This consideration simplifies the present analysis.

\subsection{Recoverable Power Potential}

The main focus of the present paper is the estimation of recoverable power from regenerative brakes. Therefore, the most important term of the force balance, Equation (1), is related to the brake system. Black boxes in the locomotives register information such as time, velocity, direction, distance run, throttle notch, brake usage that can be pneumatic (automatic or independent brake) or electrical (dynamic brake). Such information is stored on a second basis and is available in a data bank. The energy consumption by motors and the energy dissipation by brakes can be estimated by using these data.

Thus, the implemented program or MatLab ${ }^{\circledR}$ script reads the data bank from black boxes recorded in real railway trips and converts the data in an estimate demand profile, calculating the energy excess. In order to illustrate, the black box data bank is similar to the data presented in Table 3.

Table 3. Sample of data from the train's black box during a trip.

\begin{tabular}{cccc}
\hline Time & Velocity $\mathbf{( k m} / \mathbf{h})$ & Notch Position & Dynamic Brake (\%) \\
\hline 00:00 & 32 & Pos. 1 & 0 \\
\hline $00: 01$ & 32 & Neutral & 0 \\
\hline $00: 02$ & 32 & Neutral & 0 \\
\hline $00: 03$ & 32 & Dynamic brake & 5 \\
\hline $00: 04$ & 32 & Dynamic brake & 10 \\
\hline
\end{tabular}

One can estimate the power requirement from the Davis equation to calculate the losses and the track profile to calculate the force balance (Equation (1)). The excess energy from braking can 
be obtained from the power formulated by Equation (7) together with the data from the black box presented in Table 3, second by second. Thus, it is possible to find the total amount of recoverable energy from the system. Based on this information, the optimal size of a storage system can be determined, based on storage systems characteristics.

\subsection{Determining the Size of the Energy Storage}

The energy balance previously presented with the data from the dynamic brake recorded at the black box is performed second by second. The flowchart in Figure 3 presents the algorithm to estimate the recovery capacity. This analysis is repeated for different energy storage sizes. The energy recovered and the energy curtailment when the battery is full is accounted to be used in the economic analysis.

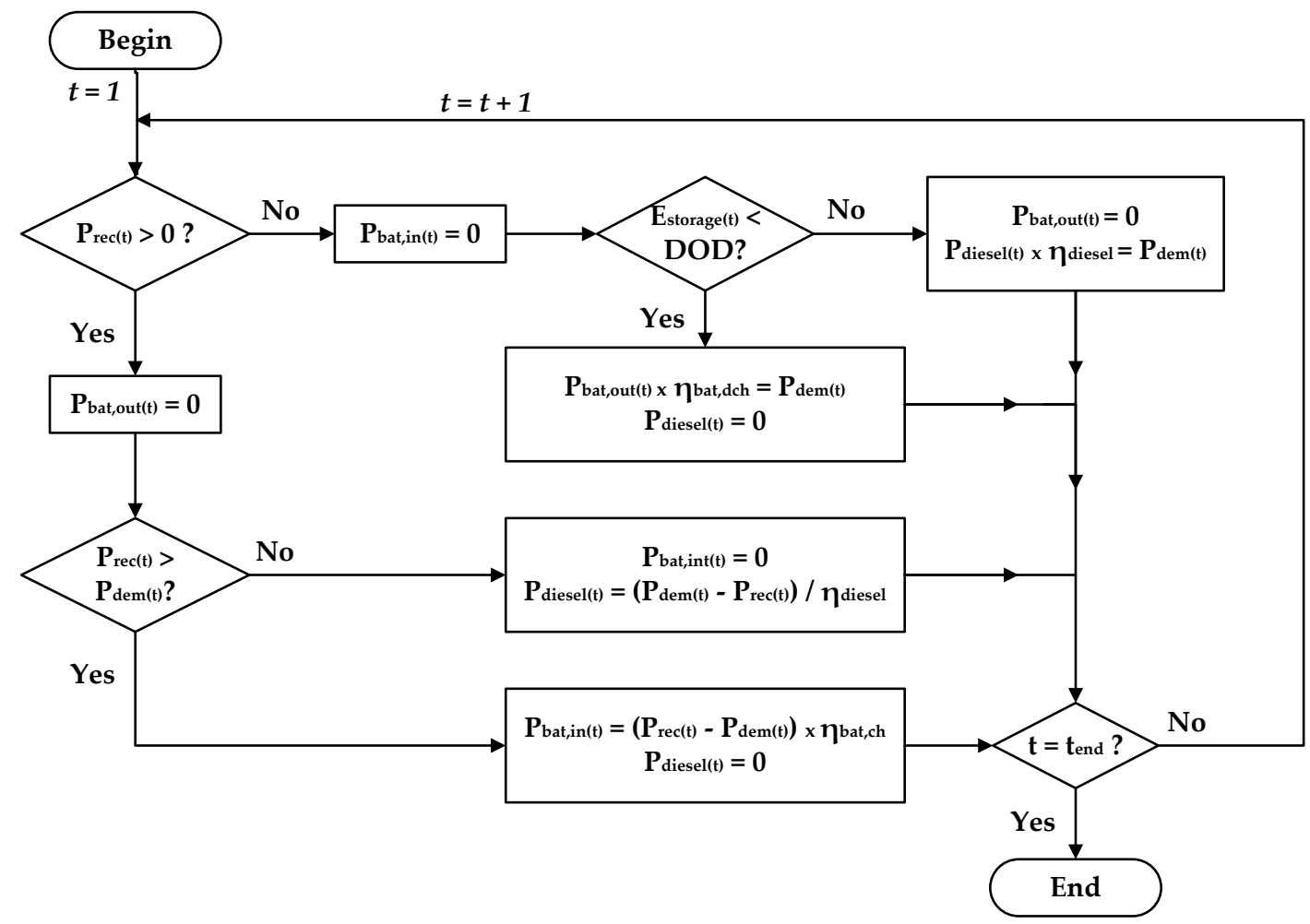

Figure 3. Flowchart to calculate the power involved in the process, every second.

The amount of power in $\left(P_{b a t, i n}\right)$ or power out $\left(P_{b a t, o u t}\right)$ from the battery, as well as the amount of diesel $\left(P_{\text {diesel }}\right)$ are defined based on the recoverable potential $\left(P_{\text {rec }}\right)$, the energy level $\left(E_{\text {storage }}\right)$, the battery charge $\left(\eta_{\text {bat,ch }}\right)$ and discharge $\left(\eta_{\text {bat }, \text { dch }}\right)$ efficiencies, diesel engine efficiency $\left(\eta_{\text {diesel }}\right)$, and the power demand $\left(P_{d e m}\right)$ at each time interval.

During dynamic braking, the battery bank stores energy. When the brake dynamics have been turned off, the battery bank contributes to the power demand. The power balance, second by second, referenced from to the power electric demand, is presented in Equation (8) during dynamic braking and in Equation (9) for the train's motor traction operation mode.

$$
\begin{gathered}
P_{\text {rec }}(t)+P_{\text {diesel }}(t) \times \eta_{\text {diesel }}=P_{\text {bat }, \text { in }}(t) \times \eta_{\text {bat }, \text { ch }}+P_{\text {dem }}(t) \\
P_{\text {diesel }}(t) \times \eta_{\text {diesel }}+P_{\text {bat }, \text { out }}(t) \times \eta_{\text {bat }, \text { dch }}=P_{\text {dem }}(t)
\end{gathered}
$$

The $P_{b a t, \text { in }}$ and $P_{b a t, o u t}$ have upper bounds defined by the rated power of charge $\left(P_{\max , c h}\right)$ and discharge $\left(P_{\max , d c h}\right)$, respectively. The $E_{\text {storage }}$ is bounded by the depth of discharge (DOD) and 
maximum state of charge $\left(S O C_{\max }\right)$. If $E_{\text {storage }}(t)=S O C_{\max }, P_{\text {bat }, \text { in }}(t)=0$, whereas $E_{\text {storage }}(t)=D O D$ implies $P_{\text {bat }, \text { out }}(t)=0$.

With the power injection or extraction from the ESS, the demand profile is determined in order to estimate the size of the ESS. By comparing the demand of diesel when considering the ESS and the regenerative brake with the situation without ESS, one can estimate the financial economy, as the diesel is the only sort of fuel used in this kind of freight train. Thus, the economy is determined from comparison involving the integral of the variable $P_{\text {diesel }}$ in each previous situation.

The maximum values for the power injection $\left(P_{b a t, i n}\right)$, extraction $\left(P_{b a t, o u t}\right)$, and energy storage $E_{\text {storage }}$ must be defined according to the type of ESS under evaluation. A direct way to achieve the optimal size of ESS, whatever kind of technology considered, can be by simulating different system sizes.

Notice either the battery or diesel engine is working at traction stage, i.e., the battery can be considered as the primary power supplier compared with diesel engine at this stage, through a system known as auto engine start stop (AESS).

\subsection{Economic Analysis}

In order to properly evaluate the proposed solution, it is necessary to consider economic parameters to guarantee a proper return on the investment for the railway company. Thus, the net present value (NPV) can be considered at first. Additionally, the intern return rate (IRR) and the payback period can be of interest to companies even considering the drawbacks of the use of both methods [40].

The NPV is a significant parameter for the economic analysis of projects. It seeks to evaluate the viability of a given project and is based on the calculation of the present value of a series of future payments, subtracted by the capital expenditures. The NPV equation is represented in Equation (10).

$$
N P V=-C A P E X+\sum_{t=1}^{k} \frac{C F_{t}}{(1+i)^{t}}
$$

where $C F_{t}$ is the cash flow of each period $t$ and $i$ is the discount rate considered that depends on the risk of the investment, the company's opportunity cost, and liquidity. This discount rate is usually called minimum attractive rate of return (MARR) and varies from company to company.

The internal rate of return (IRR) is another important parameter when evaluating a project and is defined as the rate of return that turns the NPV equal to zero. Thus, IRR represents the rate of return of a given project and can be compared with the MARR. Given an IRR greater than the MARR, the investment is economically attractive [41].

Another general financial index is the payback period, which is the time required to recover the capital invested. In order to better consider the time value of money, the discounted payback period is used in the present work [42].

Given the technical parameters of the storage device for the energy recovery from the regenerative brake, it is possible to conduct a preliminary economic analysis of the investment. Therefore, the investment analysis indexes are calculated for each proposed size of storage device.

\section{Results}

\subsection{Energy Balance}

This present work makes use of data close to a real Brazilian railway, that is, it is based on the operational data from MRS Logística S/A. In this heavy hull system the trains, when empty, are composed of 136 wagons of 20 tons each and two $4400 \mathrm{HP}$ locomotives of 195 tons each, thus 3115 tons in total. In a full load trip there are three $4400 \mathrm{HP}$ locomotives of 195 tons with 136 wagons of 125 tons each, thus a total of 17,390 tons. 
From Table 2 and Equation (8), that relates data from locomotives' black boxes with the diesel oil consumption, it is possible to define a consumption profile during a trip, based on the railway data. The same procedure can be done with information of power dissipation in dynamic brakes.

Considering a complete trip (see Figure 4), that starts at loading point $\mathrm{A}$ and finishes at unloading point B. Then it turns back empty, from B to A. Emulating a real case the loading point A corresponds to Andaime Railway Station (TFA), in the city of Itabirito while point B represents Ilha Guaíba Railway Station (TIG), a port located in Mangaritiba-Rio de Janeiro. This route is used to transport iron ore to exportation. The total time of each round trip takes about $28 \mathrm{~h}$ and the train complete about 12 trips each month.

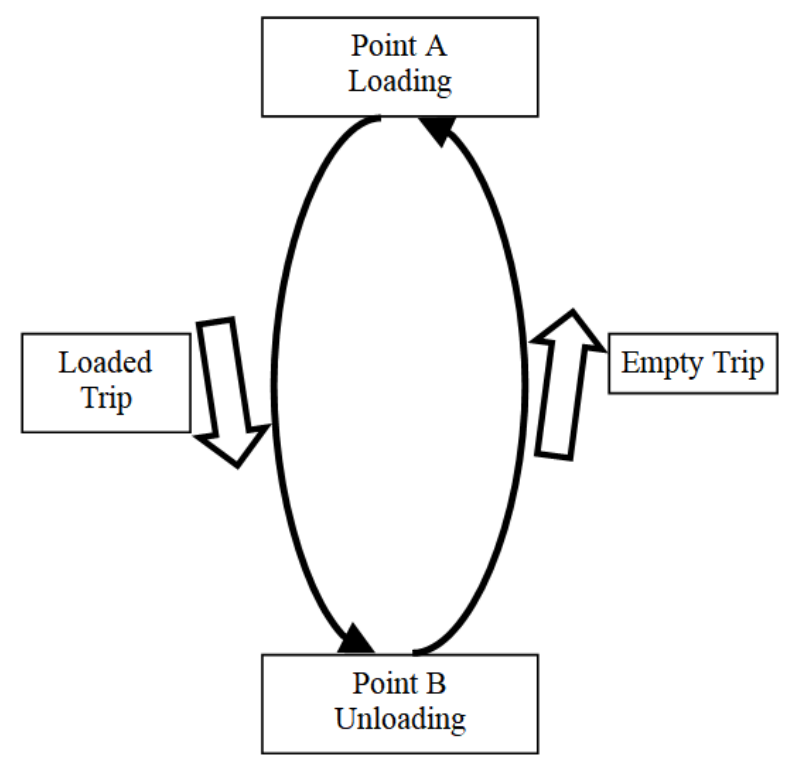

Figure 4. Railway considered in the case study.

Following the proposed methodology, the first step consists of calculating the maximum recoverable energy potential. In this stage no limit to the regenerative braking system in terms of power or energy is considered. Figure 5 presents the demand profile for part of the trip previously mentioned in Figure 4. The demand profile with and without energy recovery can be seen, and also that the regenerative brake can reduce the demand in many moments of the trip, thus presenting an energy economy.

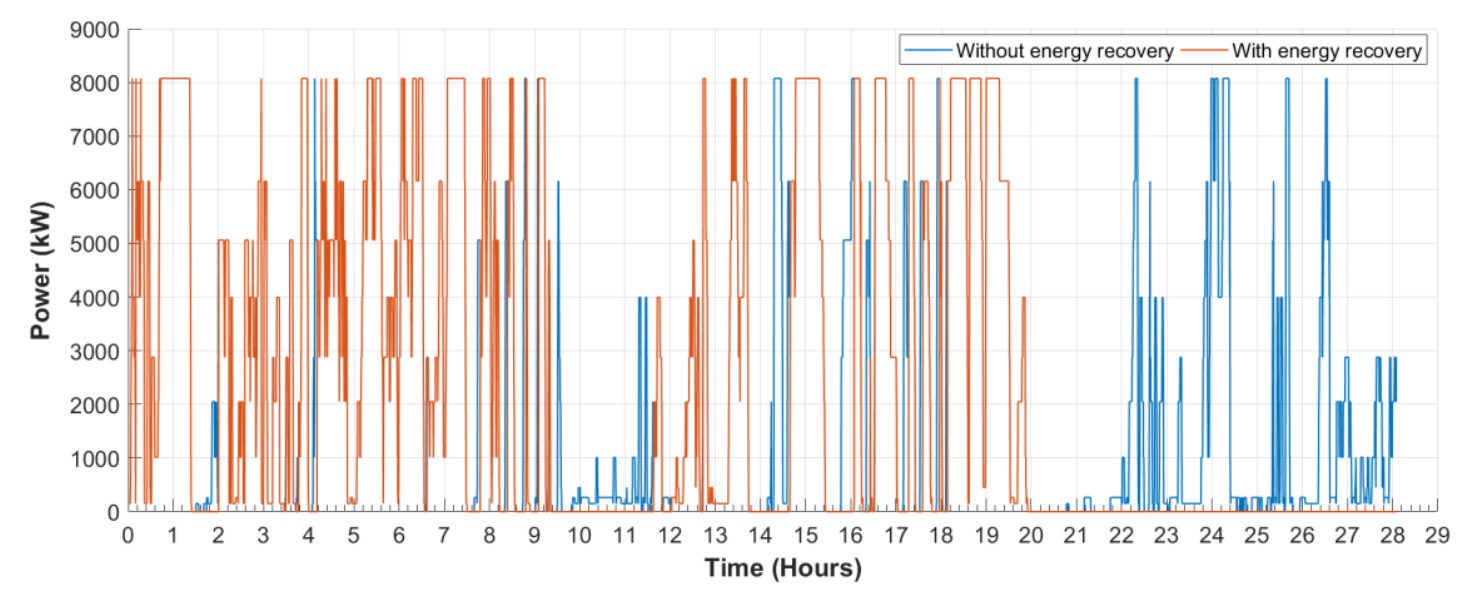

Figure 5. Demand profile with and without energy recovery (part of the trip). 
The results considering the whole trip for both cases can be seen in Table 4 . Those values give a first suggestion of the size of the regenerative brake system. A total of $23.87 \%$ of the economy can be seen as part of the energy wasted during braking. There is still the parcel related to the pneumatic brakes.

Table 4. Recoverable potential without limiting the storage capacity.

\begin{tabular}{ccc}
\hline & Consumption (kWh) & Economy (\%) \\
\hline Without energy recovery & $78,740.54$ & - \\
\hline With energy recovery & $59,948.42$ & $23.87 \%$ \\
\hline
\end{tabular}

Figures 6 and 7 present the recovered power and remaining energy in the battery without considering a power or energy limit to the regenerative braking, that is, all the energy from the brakes can be recovered.

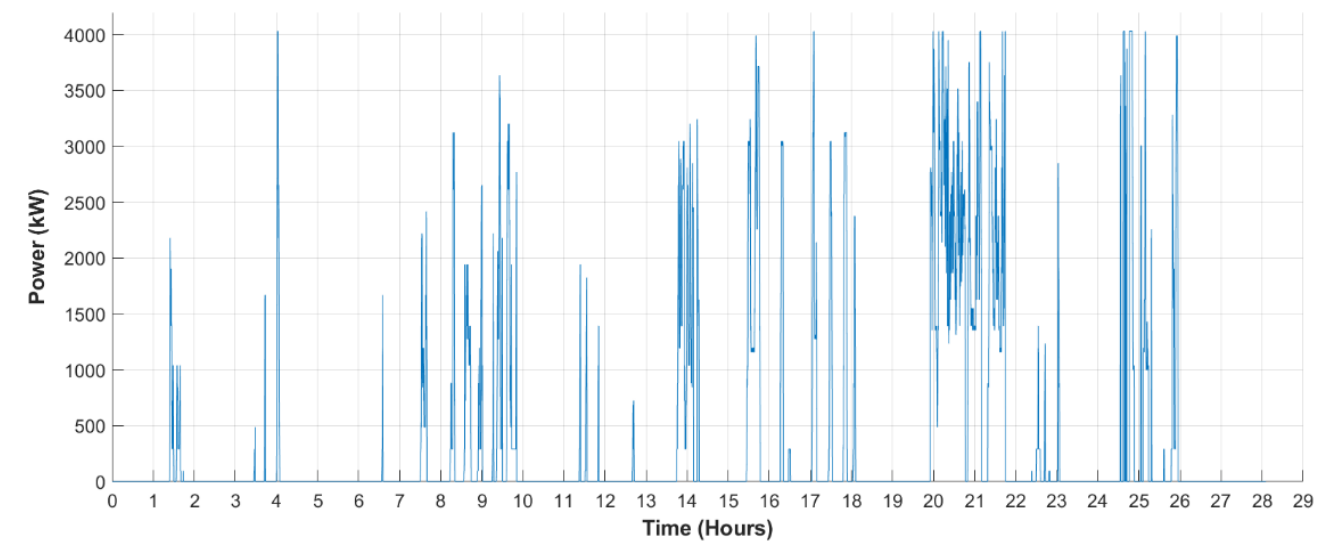

Figure 6. Recovered power (without limit to the storage size).

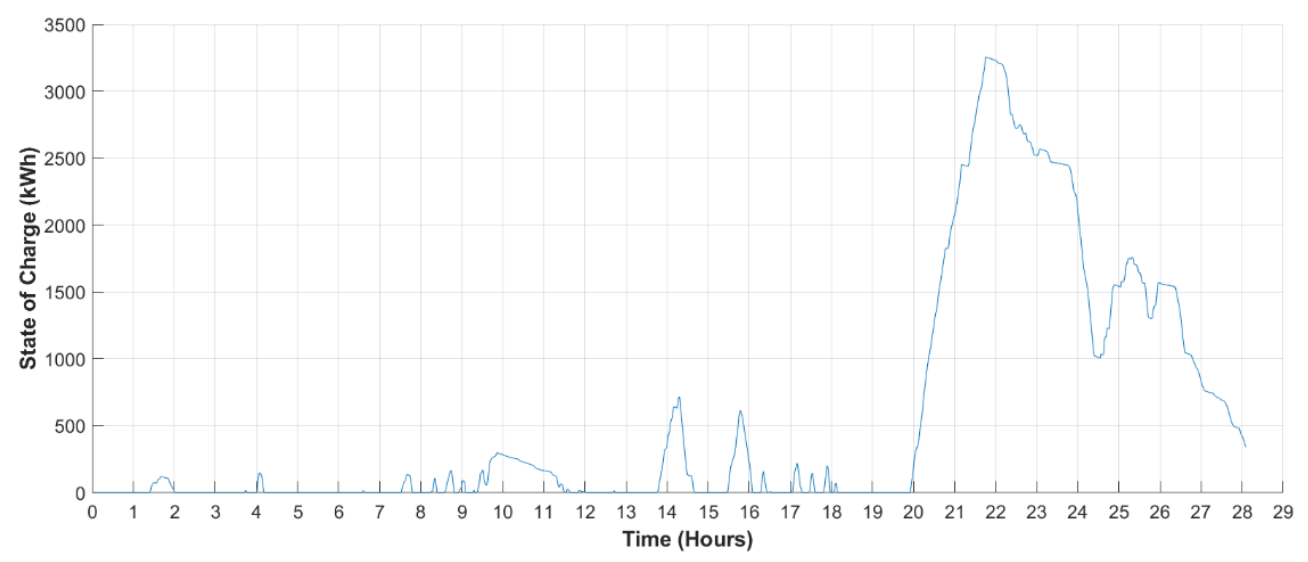

Figure 7. Remaining energy (without limit to the storage size).

Given the main features of the potential recoverable energy, the next step consists of defining the kind of storage device will be used in the proposed application. Even more, it can be noted that the maximum recoverable power and maximum energy level of the storage application are very high, which means a high investment cost. Thus, it is necessary to consider optimal sizing of the storage device. 


\subsection{Optimal Sizing of Energy Storage System}

In this work, the authors classified the different types of storage devices according to the energy capacity and time of discharge. Considering the characteristics of the railway system under study, the best choice is a battery bank, and the technology selected was Lithium Titanium Oxide (LTO) [43].

Given the input data, presented in Table 5, the proposed methodology was implemented in MatLab ${ }^{\circledR}$ considering different energy capacities for the storage system, up to $3000 \mathrm{kWh}$. Figure 8 shows that the $950 \mathrm{kWh}$ system presents the best result, with an NPV of R\$1,888,465.24 (or US\$ $470,938.96)$ in a 10-year horizon.

Table 5. Input data to model the optimal size of the storage system.

\begin{tabular}{lccc}
\hline \multicolumn{1}{c}{ Variable } & Value & Unit & Reference \\
\hline Initial investment & 469.00 & $\mathrm{US} \$ / \mathrm{kWh}$ & {$[44]$} \\
Maximum C-rate charge/discharge battery & $3 \mathrm{C}$ & $\mathrm{kW}$ & {$[43]$} \\
Depth of discharge battery & 80 & $\%$ & {$[43]$} \\
State of charge battery range & $20-90$ & $\%$ & {$[43]$} \\
Efficiency charge/discharge battery & 92 & $\%$ & {$[31]$} \\
Efficiency diesel engine & 37 & $\%$ & {$[36]$} \\
Lifespan of the battery & $>20,000$ & cycles & {$[43]$} \\
Lifespan of the system & 10 & years & \\
Brazilian Real to US\$ exchange rate & 4.01 & $\mathrm{R} \$ / \mathrm{US} \$$ & {$[45]$} \\
Fuel cost (diesel oil) & 3.69 & $\mathrm{R} \$ / \mathrm{L}$ & {$[46]$} \\
Fuel costs increase rate & 8.33 & $\%$ yearly & {$[46]$} \\
Discount rate (in NPV)/MARR & 1.5 & $\%$ monthly & {$[47]$} \\
\hline
\end{tabular}

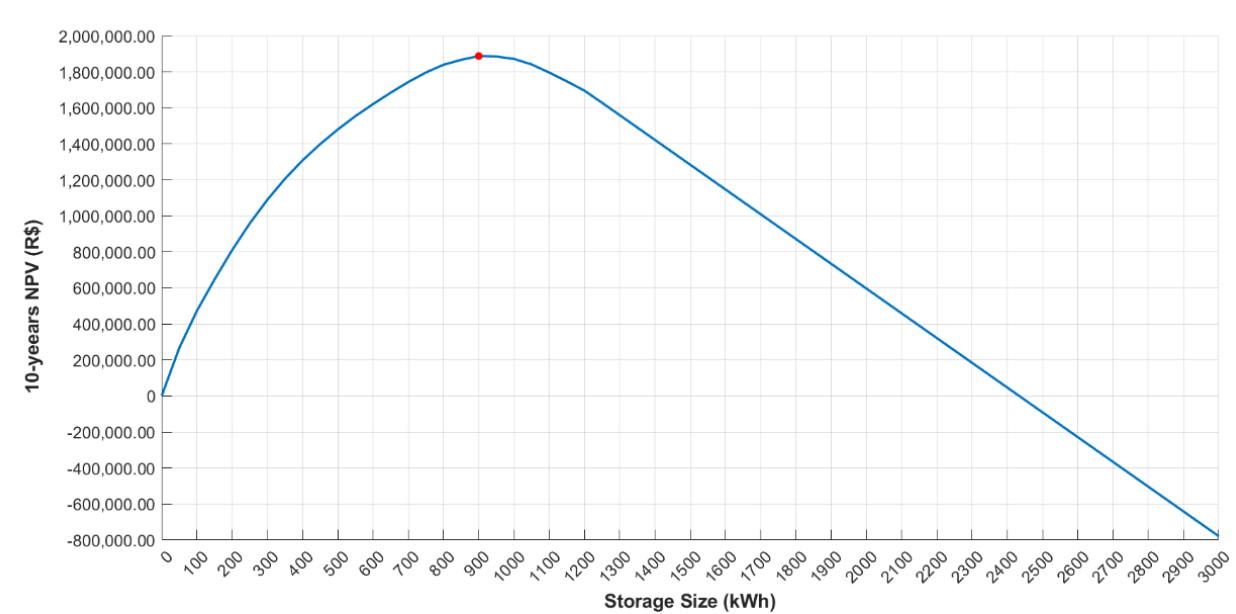

Figure 8. Storage system optimal sizing.

Considering the storage system presented, the recoverable power and the load levels in the storage system are presented in Figures 9 and 10. 


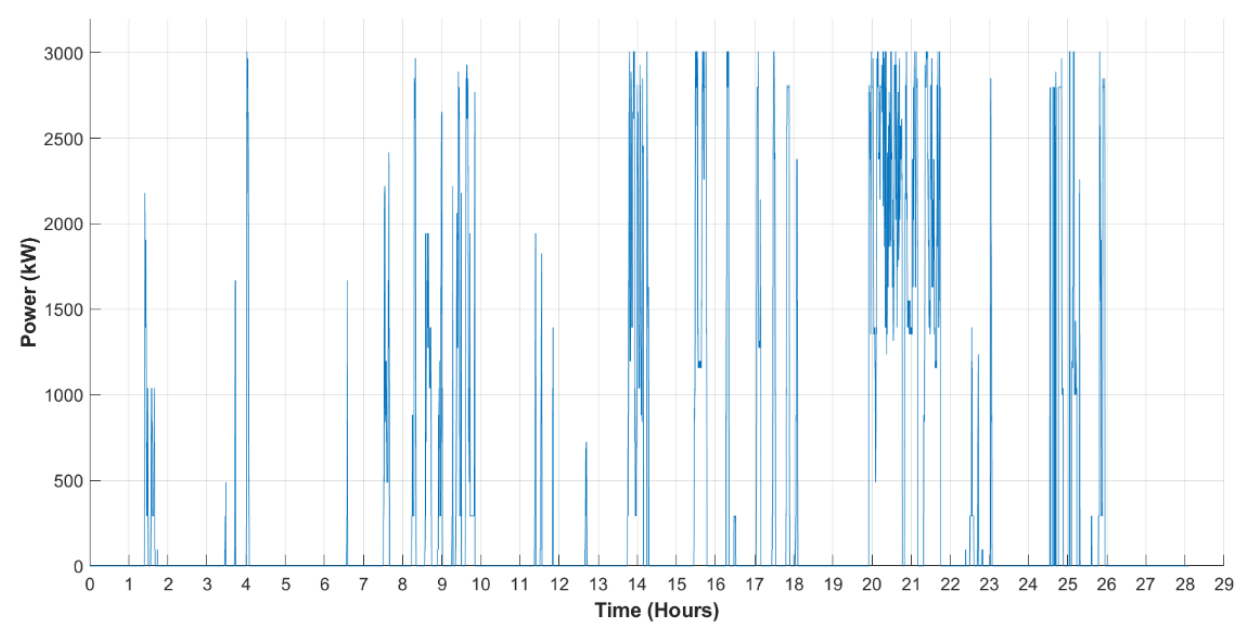

Figure 9. Recovered power (considering storage limits).

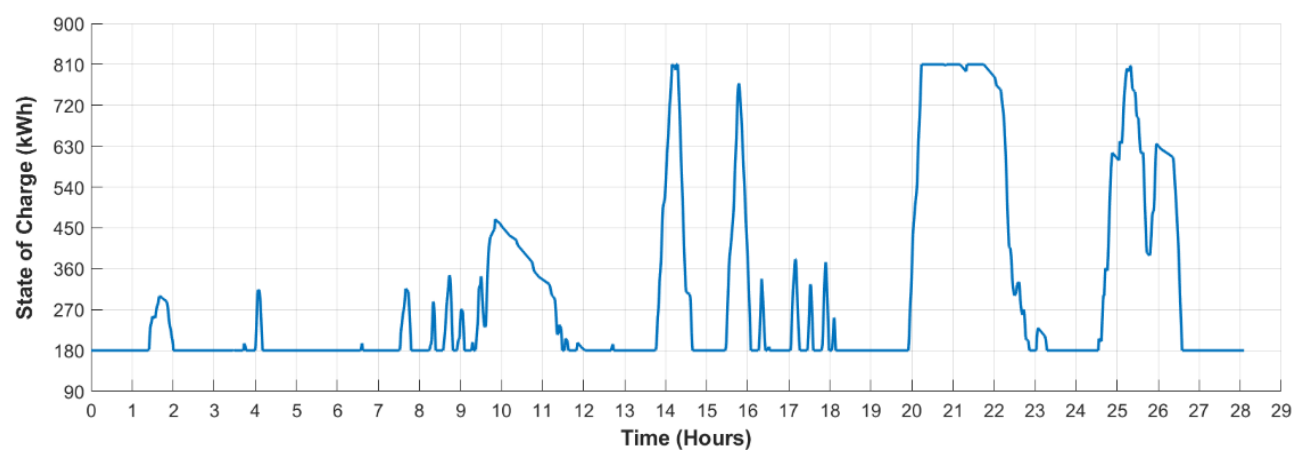

Figure 10. Energy accumulation (considering storage limits).

Defining the storage device limits, it is possible to recalculate the values in Table 5, estimating the economy due to the regenerative brake system's energy recovery, as seen in Table 6.

Table 6. Recoverable potential with limiting the storage capacity.

\begin{tabular}{ccc}
\hline & Consumption (kWh) & Economy (\%) \\
\hline Without energy recovery & $78,740.54$ & - \\
\hline With energy recovery & $66,399.48$ & $15.67 \%$ \\
\hline
\end{tabular}

\subsection{Detailed Financial Results}

The US\$ 469.00/kWh capital expenditure represents the investment cost in the storage system taking into account the capital cost of the energy capacity (271.00 US\$ $/ \mathrm{kWh}$ ), power conversion system (72 USS $\$ / \mathrm{kW}$ ), balance of plant (25 US\$/kWh), and construction and commissioning (101 US\$/kWh) [44].

The LTO batteries selected as the technology to this present application have been used in distribution and transmission power systems, or grid-scale and railway transportation system applications. Thus, they are used in applications with high levels of energy size and power density, similar to the present study case. The cost and technical aspects to the LTO and other batteries technologies are available in $[31,44]$

The fuel cost adopted in the present work was considered as the mean cost practiced by the oil distribution companies in the Minas Gerais State, Brazil, in October 2019, according to the Brazilian National Agency of Petroleum, Natural Gas and Biofuels (ANP) [46]. Additionaly, the annual increase was defined as the mean historical increase based on the ANP records. 
The Brazilian Real to US\$ exchange rate was considered on 4 November 2019 [45]. The discount rate used in this paper represents the MARR [47] and is dependent on capital costs of each company. Thus, this rate was defined as an expected return rate found in the market.

This project presents a positive NPV of R $\$ 1,888,465.24$ (or US $\$ 470,938.96$ ) during the 10-year lifespan given by the manufacturer. Thus, this is a viable investment according to the chosen MARR. Additionally, this investment presents a payback period of 35 months and a discounted payback period with a $1.5 \%$ monthly MARR of 43 months.

The intern return rate (IRR) of this investment is $6.2 \%$ monthly that can be compared to the MARR of each company, especially railway companies.

\section{Conclusions}

This paper presented a preliminary analysis of a storage system to recover energy from regenerative braking considering diesel-electric freight trains in non-electrified railways. The proposed analysis includes the evaluation of the inherent energy balance involving each term and the information from the train black box, after a real trip, which provided a practical evaluation. In this sense, the proposed approach was applied to real data from MRS Logística S/A, a Brazilian Railway company. The recovery potential was calculated, then, the optimal size of the storage system was defined based on the NPV. As a preliminary investment analysis study, the results of this paper may help to guide the projects and also to better define the viability and the execution plan. In a general manner, based on the positive NPV and a relatively small payback from the obtained result, it can be concluded that the energy recovery from regenerative braking is a feasible investment and may be highly recommended when dealing with the necessity to increase the efficiency in transportation and also to improve the low-carbon mobility. Notice that, in the present work, the initial investments already comprise the maintenance and installation of the storage system. Even though, future research could be conducted to define the power electronics costs that must be implemented to process the energy recovery.

Author Contributions: Conceptualization, S.M.J., J.G.O. and B.H.D.; Data curation, S.M.J.; Formal analysis, J.G.O., B.H.D. and J.S.O.; Funding acquisition, J.S.O.; Investigation, L.W.O., J.S.O. and G.S.R.; Methodology, S.M.J., J.G.O., B.H.D., J.S.O. and G.S.R.; Software, S.M.J. and G.S.R.; Supervision, J.G.O. and B.H.D.; Validation, S.M.J., J.G.O., B.H.D., L.W.O. and G.S.R.; Writing-original draft, S.M.J., J.G.O., B.H.D., L.W.O. and J.S.O.; Writing-review and editing, S.M.J., J.Oliveira, B.H.D., L.W.O., J.S.O. and G.S.R. All authors have read and agreed to the published version of the manuscript.

Funding: This research received no external funding.

Acknowledgments: The authors would like to thank the National Council for Scientific and Technological Development-CNPq, the Coordenação de Aperfeiçoamento de Pessoal de Nível Superior-CAPES, the State of Minas Gerais Research Foundation-FAPEMIG and INERGE for their financial and/or technical support in the development of this paper. This work was conducted within the STandUP for Energy strategic research framework.

Conflicts of Interest: The authors declare no conflict of interest.

\section{Nomenclature}

A Resistance coefficient due to the wheel-rail friction $(\mathrm{kgf} / \mathrm{tf})$

$B \quad$ Resistance coefficient due to the bearings' friction (kgf.h/tf.km)

C Resistance coefficient due to the air friction (kgf.h2/tf.km)

CAPEX Initial investiment (R\$)

$C F_{t} \quad$ Cash flow in period $t(\mathrm{R} \$)$

DOD Depth of the discharge $(\mathrm{kWh})$

$E_{\text {storage }(t)} \quad$ Stored energy in instant $t(\mathrm{kWh})$

$F_{a t} \quad$ Friction force $(\mathrm{kN})$

$F_{\text {friction }} \quad$ Force resulting from the resistance to the movement $(\mathrm{kN})$

$F_{\text {gravity }} \quad$ Force related to the gravity $(\mathrm{kN})$

$F_{\text {mot } / \text { brake }}$ Train force (motor or brake) $(\mathrm{kW})$

$g \quad$ Gravitational acceleration $\left(\mathrm{m} / \mathrm{s}^{2}\right)$

i Discount rate 
$k \quad$ Investment lifespan (months)

M Vehicle's mass (ton)

$M_{\text {train }} \quad$ Mass of the whole train (ton)

$n \quad$ Number of axes

NPV Net presente value (R\$)

$N_{w} \quad$ Number of wagons

$P_{a t} \quad$ Power losses due to friction (kW)

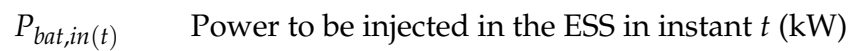

$P_{\text {bat }, \text { out }(t)} \quad$ Power to be extracted from the ESS in instant $t(\mathrm{~kW})$

$P_{\text {dem }(t)} \quad$ Power demand in instant $t(\mathrm{~kW})$

$P_{\text {diesel }(t)} \quad$ Power from diesel oil in instant $t(\mathrm{~kW})$

$P_{\text {max }, \text { ch }} \quad$ Maximum rate power charge $(\mathrm{kW})$

$P_{\text {max }, \text { dch }} \quad$ Maximum rate power discharge $(\mathrm{kW})$

$P_{\text {rec }(t)} \quad$ Recoverable power in instant $t(\mathrm{~kW})$

$S \quad$ Vehicle's frontal area $\left(\mathrm{m}^{2}\right)$

SC Standard consumption $(\mathrm{l} / \mathrm{h})$

$S O C_{\max } \quad$ Maximum state of the charge $(\mathrm{kWh})$

$T \quad$ Resulting weight in the direction of the movement $(\mathrm{N})$

$v \quad$ Vehicle's velocity $(\mathrm{km} / \mathrm{h})$

$W_{\text {acceleration }}$ Acceleration of the train $\left(\mathrm{m} / \mathrm{s}^{2}\right)$

Pbrake Power dissipated in the dynamic brakes $(\mathrm{kW})$

$P_{\text {friction }} \quad$ Power term representing the friction $(\mathrm{kW})$

$P_{\text {gravity }} \quad$ Power gains or losses related to the gravity (kW)

$P_{\text {mot/brake }} \quad$ Weight power of the train $(\mathrm{kW})$

$\gamma_{a t} \quad$ Friction coefficient $(\mathrm{kgf} / \mathrm{tf})$

$\alpha \quad$ Inclination angle

$\rho \quad$ Energy density of the fuel (diesel) $(\mathrm{kWh} / \mathrm{L})$

$\left(\eta_{\text {bat }, c h}\right) \quad$ Charge battery efficiency

$\left(\eta_{b a t, d c h}\right) \quad$ Discharge battery efficiency

$\left(\eta_{\text {diesel }}\right) \quad$ Diesel engine efficiency

$\%$ Percentual of application of the dynamic brake

\section{References}

1. Song, Y.; Song, W. A novel dual speed-curve optimization based approach for energy-saving operation of high-speed trains. IEEE Trans. Intell. Transp. Syst. 2016, 17, 1564-1575. [CrossRef]

2. González-Gil, A.; Palacin, R.; Batty, P. Sustainable urban rail systems: Strategies and technologies for optimal management of regenerative braking energy. Energy Convers. Manag. 2013, 75, 374-388. [CrossRef]

3. Roch-Dupré, D.; López-López, A.J.; Pecharromán, R.R.; Cucala, A.P.; Fernández-Cardador, A. Analysis of the demand charge in DC railway systems and reduction of its economic impact with Energy Storage Systems. Int. J. Electr. Power Energy Syst. 2017, 93, 459-467. [CrossRef]

4. Liu, J.; Guo, H.; Yu, Y. Research on the cooperative train control strategy to reduce energy consumption. IEEE Trans Intell. Transp. Syst. 2017, 18, 1134-1142. [CrossRef]

5. Arboleya, P.; Bidaguren, P.; Armendariz, U. Energy is on board: Energy storage and other alternatives in modern light railways. IEEE Electr. Mag. 2016, 4, 30-41. [CrossRef]

6. Yang, X.; Chen, A.; Li, X.; Ning, B.; Tang, T. An energy-efficient scheduling approach to improve the utilization of regenerative energy for metro systems. Transp. Res. Part C Emerg. Technol. 2015, 57, 13-29. [CrossRef]

7. Ceraolo, M.; Lutzemberger, G.; Meli, E.; Pugi, L.; Rindi, A.; Pancari, G. Energy storage systems to exploit regenerative braking in DC railway systems: Different approaches to improve efficiency of modern high-speed trains. J. Energy Storage 2018, 16, 269-279. [CrossRef]

8. Lu, S.; Weston, P.; Hillmansen, S.; Gooi, H.B.; Roberts, C. Increasing the regenerative braking energy for railway vehicles. IEEE Trans Intell. Transp. Syst. 2014, 15, 2506-2515. [CrossRef] 
9. Domínguez, M.; Fernández-Cardador, A.; Cucala, A.P.; Pecharromán, R.R. Energy savings in metropolitan railway substations through regenerative energy recovery and optimal design of ATO speed profiles. IEEE Trans. Autom. Sci. Eng. 2014, 9, 496-504. [CrossRef]

10. Yoshida, Y.; Figueroa, H.P.; Dougal, R.A. Comparison of energy storage configurations in railway microgrids. In Proceedings of the IEEE Second International Conference DC Microgrids (ICDCM), Nuremburg, Germany, 27-29 June 2017; pp. 133-138.

11. Ratniyomchai, T.; Hillmansen, S.; Tricoli, P. Recent developments and applications of energy storage devices in electrified railways. IET Electr. Syst. Transp. 2014, 4, 9-20. [CrossRef]

12. Konishi, T.; Morimoto, H.; Aihara, T.; Tsutakawa, M. Fixed energy storage technology applied for DC electrified railway. IEE J. Electr. Electron. Eng. 2010, 5, 270-277. [CrossRef]

13. Torre, S.; Sánchez-Racero, A.J.; Aguado, J.A.; Reyes, M.; Martínez, O. Optimal sizing of energy storage for regenerative braking in electric railway systems. IEEE Trans. Power Syst. 2015, 30, 1492-1500. [CrossRef]

14. Zhu, F.; Yang, Z.; Xia, H.; Lin, F. Hierarchical control and full-range dynamic performance optimization of supercapacitor energy storage system in urban railway. IEEE Trans. Indust. Electron. 2018, 65, 6646-6656. [CrossRef]

15. Bartłomiejczyk, M.; Połom, M. Multiaspect measurement analysis of braking energy recovery. Energy Convers. Manag. 2016, 127, 35-42. [CrossRef]

16. Aguado, J.A.; Racero, A.J.S.; Torre, S. Optimal operation of electric railways with renewable energy and electric storage systems. IEEE Trans. Smart Grid 2016, 9, 993-1001. [CrossRef]

17. Liu, Y.; Chen, M.; Lu, S.; Chen, Y.; Li, Q. Optimized Sizing and Scheduling of Hybrid Energy Storage Systems for High-Speed Railway Traction Substations. Energies 2018, 11, 2199. [CrossRef]

18. Steiner, M.; Scholten, J. Energy storage on board of railway vehicles. In Proceedings of the European Conference Power Electronics Applications, Dresden, Germany, 11-14 September 2005; p. 10.

19. Corbo, P.; Corcione, F.E.; Migliardini, F.; Veneri, O. Energy management in fuel cell power trains. Energy Convers. Manag. 2006, 47, 3255-3271. [CrossRef]

20. Painter, T.D.; Barkan, C.P.L. Prospects for dynamic brake energy recovery on North American freight locomotives. In Proceedings of the 2006 IEEE/ASME Joint Rail Conference, Atlanta, GA, USA, 4-6 April 2006; pp. 181-188.

21. Douglas, H.; Roberts, C.; Hillmansen, S.; Schmid, F. An assessment of available measures to reduce traction energy use in railway networks. Energy Convers. Manag. 2015, 106, 1149-1165. [CrossRef]

22. Yang, X.; Li, X.; Ning, B.; Tang, T. A survey on energy-efficient train operation for urban rail transit. IEEE Trans. Intell. Transp. Syst. 2015, 17, 2-13. [CrossRef]

23. Khodaparastan, M.; Mohamed, A.A.; Brandauer, W. Recuperation of regenerative braking energy in electric rail transit systems. IEEE Trans. Intell. Transp. Syst. 2019, 20, 2831-2847. [CrossRef]

24. Tian, Z.; Weston, P.; Zhao, N.; Hillmansen, S.; Roberts, C.; Chen, L. System energy optimisation strategies for metros with regeneration. Transp. Res. Part. C Emerg. Technol. 2017, 75, 120-135. [CrossRef]

25. González-Gil, A.; Palacin, R.; Batty, P. Optimal energy management of urban rail systems: Key performance indicators. Energy Convers. Manag. 2015, 90, 282-291.

26. Frilli, A.; Meli, E.; Nocciolini, D.; Pugi, L.; Rindi, A. Energetic optimization of regenerative braking for high speed railway systems. Energy Convers. Manag. 2016, 129, 200-215. [CrossRef]

27. Ciccarelli, F.; Iannuzzi, D.; Tricoli, P. Control of metro-trains equipped with onboard supercapacitors for energy saving and reduction of power peak demand. Transp. Res. Part. C Emerg. Technol. 2012, 24, 36-49. [CrossRef]

28. International Electrotechnical Commission. Electrical Energy Storage; International Electrotechnical Commission: Geneva, Switzerland, 2011.

29. Møller, K.T.; Jensen, T.R.; Akiba, E.; Li, H.W. Hydrogen-A sustainable energy carrier. Prog. Nat. Sci. Mater. Int. 2017, 27, 34-40. [CrossRef]

30. Gao, Z.; Chin, C.; Woo, W.; Jia, J. Integrated equivalent circuit and thermal model for simulation of temperature-dependent $\mathrm{LiFePO} 4$ battery in actual embedded application. Energies 2017, 10, 85. [CrossRef]

31. Irena, A.D. Electricity Storage and Renewables: Costs and Markets to 2030; International Renewable Energy Agency: Abu Dhabi, UAE, 2017. 
32. Killer, A.; Armstorfer, A.; Diez, A.E.; Biechl, H. Ultracapacitor assisted regenerative braking in metropolitan railway systems. In Proceedings of the 2012 IEEE Colombian Intelligent Transportation Systems Symposium (CITSS), Bogota, Colombia, 30 August 2012; pp. 1-6.

33. Lin, F.; Li, X.; Zhao, Y.; Yang, Z. Control strategies with dynamic threshold adjustment for supercapacitor energy storage system considering the train and substation characteristics in urban rail transit. Energies 2016, 9, 257. [CrossRef]

34. Gee, A.M.; Dunn, R.W. Analysis of Trackside Flywheel Energy Storage in Light Rail Systems. IEEE Trans. Veh. Technol. 2015, 64, 3858-3869. [CrossRef]

35. Spiryagin, M.; Wolfs, P.; Szanto, F.; Sun, Y.Q.; Cole, C.; Nielsen, D. Application of flywheel energy storage for heavy haul locomotives. Appl. Energy 2015, 157, 607-618. [CrossRef]

36. García-Garre, A.; Gabaldón, A. Analysis, evaluation and simulation of railway diesel-electric and hybrid units as distributed energy resources. App. Sci. 2019, 9, 3605. [CrossRef]

37. Reddy, T.B. Linden's Handbook of Batteries, 4th ed.; McGraw Hill: New York, NY, USA, 2011.

38. Halvor, S.; Hansen, M.U.N.; Nils, O. Using operational data to estimate the running resistance of trains. Estimation of the resistance in a set of Norwegian tunnels. J. Rail Transp. Plan. Manag. 2017, 7, 62-76.

39. Davis, W.J. The tractive resistance of electric locomotives and cars. Gen. Electr. Rev. 1926, 29, 685-708.

40. Brealey, R.A.; Myers, S.C.; Allen, F.; Mohanty, P. Principles of Corporate Finance; Tata McGraw-Hill Education: New York, NY, USA, 2012.

41. Vale, A.M.; Felix, D.G.; Fortes, M.Z.; Borba, B.S.M.C.; Dias, B.H.; Santelli, B.S. Analysis of the economic viability of a photovoltaic generation project applied to the Brazilian housing program "Minha Casa Minha Vida". Energy Policy 2017, 108, 292-298. [CrossRef]

42. Blank, L.; Tarquin, A. Engineering Economy; McGraw-Hill: New York, NY, USA, 2005.

43. Toshiba. Industrial Lithium-ion Battery SCiB ${ }^{\mathrm{TM}}$ SIP Series. Available online: https://www.scib.jp/en/product/ sip/index.htm (accessed on 1 November 2019).

44. Mongird, K.; Fotedar, V.; Viswanathan, V.; Koritarov, V.; Balducci, P.; Hadjerioua, B.; Alam, J. Energy Storage Technology and Cost Characterization Report; U.S. Department of Energy's Water Power Technologies Office by Pacific Northwest National Laboratory: Washington, DC, USA, 2019.

45. U.S. Dollar/Brazilian Real. Available online: https://www.tradingview.com/symbols/USDBRL (accessed on 4 November 2019).

46. Agência Nacional do Petróleo, Gás Natural e Biocombustíveis. Síntese dos Preços Praticados-MINAS GERAIS. Available online: http://preco.anp.gov.br/include/Resumo_Por_Estado_Municipio.asp (accessed on 1 November 2019).

47. Banco Central do Brasil. Taxa de juros. Available online: https://www.bcb.gov.br/estatisticas/txjuros (accessed on 4 November 2019).

(C) 2020 by the authors. Licensee MDPI, Basel, Switzerland. This article is an open access article distributed under the terms and conditions of the Creative Commons Attribution (CC BY) license (http://creativecommons.org/licenses/by/4.0/). 